somes and autosomes. Their crossing reactions with each other and with British material are being examined; but all indications, so far, are that they do truly represent ecotypes of the single species M. dioicum. Therefore, it appears that Löve's tetraploid plant is not characteristic of the coastal and montane races of this species (which have remained at the diploid level), but is an aberrant. It would have been most interesting if the fate of this plant, representing a potential new race, could have been followed in Nature.

Botany Department,

The University, Leeds. June 14.

${ }^{1}$ Löve, D., Hereditas, 28, 241 (1942).

${ }^{2}$ Fries, E., Bot. Not., 161 (1857).

${ }^{3}$ Turesson, G., Hereditas, 6, 147 (1925).

- Simmons, H. G., Arkiv. f. Bot., (6), 17, 1 (1907).

${ }^{5}$ Warmke, H. E., and Blakeslee, A. F, Amer, J. Bot, 27, 751 (1940).

${ }^{6}$ Baker, H. G., Ph.D. thesis, University of London.

' Baker, H. G., J. Ecol., 35, 271 (1947).

${ }^{8}$ Baker, H. G., New Phytol., 47, 131 (1948).

'Westergaard, M., Dansk Bot. Ark., 10, 1 (1940).

\section{Unusual Features of the Root System of the Oil Palm in West Africa}

ON the deep acid sands of West Africa the roots of the oil palm (Elceis guineensis) may be divided into primary, secondary, tertiary and quaternary.

The primary roots emerge radially from the trunk: base and proceed for long distances without change in diameter. In palms over two years old this diameter is very constant (about $5 \mathrm{~mm}$.). No roots have been found emerging at less than $15^{\circ}$ from the soil surface. After proceeding downwards to a depth proportional to the angle they make with the soil surface, these primary roots tend to level out and travel horizontally for considerable distances (specimens from a 12 -ft. palm have been traced for more than $40 \mathrm{ft}$. without coming to the end). They are completely unbranched and, in this soil, which is very free from obstructions, travel almost straight, occasionally tending to rise slightly. All primary roots found have been at a depth of more than 18 in.

The secondary roots emerge from the primary root within $45^{\circ}$ of the vertical diameter, the sides of the primary roots being almost entirely clear. Of these secondary roots approximately 70 per cent grow vertically upwards and the remaining 30 per cent vertically downwards. The roots that grow upwards continue until they reach the soil surface, those growing downwards being of variable length.

The tertiary roots, which are probably the main absorbing roots, emerge at right angles from the secondary roots and travel in a horizontal plane. Their length is normally limited to about $10 \mathrm{~cm}$., and the majority of them occur in the upper $10 \mathrm{~cm}$. of the soil, where their length is also greatest. They do not occur in quite the same way on secondary roots growing downwards, as the tertiary roots tend also to continue downwards, producing an effect more like an unequal dichotomy.

The quaternary roots are very short (normally less than $5 \mathrm{~mm}$.) and emerge at right angles to the tertiary roots.

Two other features of interest were noted : (I) The root system undergoes constant renovation, new primary roots emerging from the trunk base and old roots dying back from the tips. (2) New roots tend to grow along old dead roots. Whether the reason for this is nutrition or ease of spread remains to be proved by future experiments.

The importance of this type of root system to plantation practice is manifold. Thus mineral fertilizers do not need to be buried to become available to the plant, and, in fact, are likely to be more quickly and certainly absorbed if applied to the surface of the soil. Again, mechanical cultivation between the rows with implements such as disk harrows will do very little damage to roots, as the numbers of roots other than tertiary ones that will be cut will be very small.

My thanks are due to Messrs. Pamol, Limited, under whose auspices this work was done, for permission to publish this note.

Research Department, Pamol, Limited,

Sapele, Nigeria. Sept. 12.

\section{Effect of Nitrogen-fixing Blue-Green Algæ on the Growth of Rice Plants}

THe fixation of atmospheric nitrogen by blue-green algæ has been reported by Pringsheim, Molisch, Drewes, Allison and Morris, De, Stokes, Bortels, Fogg, Burris and Wilson, Shioiri and Nishigaki et $a l .{ }^{1}$; but no experiments on the effect of these algæ on the growth of rice plants have been performed.

About ten years ago one of us $^{2}$ began collecting blue-green algæ from the rice fields in various Far Eastern and South Sea regions. In the 643 samples collected, only thirteen blue-green species proved to be able to fix atmospheric nitrogen. These thirteen algæe grow abundantly in the tropical and semitropical regions of Java, Sumatra, Bormeo, the Philippine Islands, Malaya, Indo-China, Siam, Burma, Hainan, Formosa and South China; but they are scanty in Japan, North China, Manchuria, Korea and Sakhalin. They belong to the genera Tulypothrix, Nostoc, Schizothrix, Calothrix, Anabonopsis and Plectonema. Tolypothrix tenuis (from Borneo), Calothrix brevissima (from Palau Islands), Anabonopsis sp. (from Sumatra) and Nostoc sp. (from Java) were the only ones of which bacteria-free cultures were obtained in a nitrogen free medium $\left(0.3 \mathrm{gm} . \mathrm{K}_{2} \mathrm{HPO}_{4}\right.$, $0.2 \mathrm{gm}$. $\mathrm{MgSO}_{4} \cdot 7 \mathrm{H}_{2} \mathrm{O}, 0.05 \mathrm{gm}$. $\mathrm{CaCl}_{2}$, a trace of $\mathrm{FeCl}_{3}, 2 \mathrm{gm}$. glucose, and 1,000 c.c. distilled water). The total nitrogen fixed in 2 months was $9.6 \mathrm{mgm}$. in 'Tolypothrix tenuis, $5 \cdot 2 \mathrm{mgm}$. in Calothrix brevissima, $3.4 \mathrm{mgm}$. in Anaboenopsis sp. and $3.1 \mathrm{mgm}$. in Nostoc sp., estimated by the micro-Kjeldahl method.

With the help of such pure cultures the effect of these algæ on the growth of rice plants was examined

Table 1

\begin{tabular}{|c|c|c|c|c|}
\hline \multirow{2}{*}{ Experiment } & \multicolumn{4}{|c|}{ Length of leaves (cm.) } \\
\hline & $\begin{array}{l}\text { Tolypothrix } \\
\text { tenuis }\end{array}$ & $\begin{array}{c}\text { Calothrix } \\
\text { brevissima }\end{array}$ & $\begin{array}{c}\text { Anabanopsis } \\
\text { sp. }\end{array}$ & Control \\
\hline $\begin{array}{r}1 \\
2 \\
3 \\
4 \\
5 \\
6 \\
\text { Mean } \\
\text { Variance }\end{array}$ & $\begin{array}{l}75 \cdot 5 \\
78 \cdot 5 \\
80 \cdot 5 \\
84 \cdot 0 \\
89 \cdot 5 \\
80 \cdot 0 \\
81 \cdot 33 \\
19 \cdot 72\end{array}$ & $\begin{array}{l}78 \cdot 5 \\
84 \cdot 0 \\
80 \cdot 5 \\
80 \cdot 5 \\
82 \cdot 0 \\
85 \cdot 0 \\
81 \cdot 75 \\
4 \cdot 90\end{array}$ & $\begin{array}{l}70 \cdot 5 \\
76 \cdot 0 \\
75 \cdot 5 \\
78 \cdot 0 \\
78 \cdot 0 \\
80 \cdot 5 \\
76 \cdot 42 \\
9 \cdot 61\end{array}$ & $\begin{array}{c}72 \cdot 5 \\
68 \cdot 5 \\
72 \cdot 5 \\
74 \cdot 0 \\
76 \cdot 0 \\
71 \cdot 0 \\
72 \cdot 42 \\
5 \cdot 43\end{array}$ \\
\hline deviation & $4 \cdot 44$ & $2 \cdot 21$ & $3 \cdot 10$ & $2 \cdot 33$ \\
\hline
\end{tabular}

